\title{
Development and evaluation of a novel subunit vaccine for Mycoplasma gallisepticum
}

\author{
[Desenvolvimento e avaliação de uma nova vacina para Mycoplasma gallisepticum] \\ L. Moura ${ }^{1,3}$, J. Dohms ${ }^{2}$, J.M. Almeida ${ }^{3}$, P.S. Ferreira ${ }^{3}$, C.P. Biffi $i^{3}$, R.G. Backes ${ }^{3}$ \\ ${ }^{1}$ Centro de Educação Superior do Oeste - Universidade do Estado de Santa Catarina - Chapecó, SC \\ ${ }^{2}$ Delaware University, EUA \\ ${ }^{3}$ Centro de Ciências Agroveterinárias - Universidade do Estado de Santa Catarina - Lages, SC
}

\begin{abstract}
Adhesion proteins from Mycoplasma gallisepticum (MG) encoded by cytadhesion genes $m g c 1$ and $m g c 2$ were cloned into plasmid vectors and transformed into E. coli. Seventeen groups of specific-pathogen free (SPF), birds at four weeks of age were used to inoculate these two proteins (MGC1 and MGC2) mixed into an oil emulsion creating a novel MG vaccine. Six different protein concentrations $(50,100,200,400,800$, and $1000 \mu \mathrm{g} / \mathrm{bird}$ ) were tested with two equal concentration doses at four and seven weeks of age. In addition, many control groups were needed such as bacterin, membrane, no vaccine or challenge, oil emulsion alone, and no vaccine but challenged. Three weeks following the second vaccination, $50 \%$ of the birds in each treatment group were challenged with MG strain S6. The remaining birds were left as contacts to verify protection against horizontal transmission. All birds were bled before vaccinations, challenge and euthanasia. Birds were negative for MG at the first vaccination, as shown by serum plate agglutination test. At necropsy, tissue samples (trachea, lungs, and air sacs) were collected for histopathological examination. Swabs from trachea were used for PCR analysis. ELISA results showed a strong immune response to both protein preparations and almost the same response level for different doses tested, proving the immunogenic features of MGC1 and MGC2. However, humoral responses failed to prevent MG infection and disease when challenged as demonstrated by PCR and histopathology. MGC1 contact birds showed some degree of infection by PCR analysis. In addition, histopathological and ELISA results suggest that contact birds did not have enough time to develop lesions and to mount an immune response.
\end{abstract}

Keywords: evaluation, development, mycoplasmas, poultry, vaccine

\section{RESUMO}

Os genes mgc1 e mgc2, codificadores de duas proteínas de adesão (MGC1 e MGC2) da bactéria Mycoplasma gallisepticum, foram clonados em E. coli. Dezessete grupos de aves livres de patógenos específicos (SPF), com quatro semanas de idade, foram inoculados com uma emulsão oleosa contendo as proteínas MGC1 e MGC2

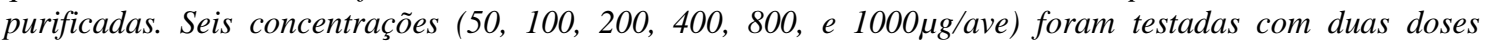
idênticas, às quatro e sete semanas de vida, respectivamente. Além disso, grupos controles foram avaliados com uma vacina comercial contra micoplasmose aviária, membrana de MG, grupo sem vacina/sem desafio, grupo vacina oleosa de MGC1 sem desafio, grupo com vacina oleosa de MGC2 sem desafio, grupo desafiado mas sem vacina. Três semanas após a segunda e a última vacinação, 50\% dos animais dos grupos tratamentos foram desafiados com a cepa S6 de MG. O restante dos animais foi deixado como contato para averiguar proteção contra a transmissão horizontal da doença. Amostras de sangue de todas as aves foram coletadas antes das vacinações, do desafio e da eutanásia. As aves eram negativas para MG às quatro semanas de vida, conforme visto na aglutinação em placa. Na necropsia, tecidos (traqueia, pulmão e sacos aéreos) foram coletados para exame histopatológico. Suabes da traqueia foram utilizados para a PCR. Os resultados do ELISA demonstraram forte resposta imune contra as duas proteínas testadas e resposta similar independentemente do número de doses, provando a sua capacidade imunogênica. Porém, esta resposta humoral gerada foi incapaz de prevenir a infecção e a doença após desafio, conforme demonstrado pelos exames PCR e histopatológico. Aves-contato, inoculadas com MGC1, demonstraram estar infectadas nas

Recebido em 14 de março de 2011

Aceito em 20 de julho de 2012

E-mail: lenita-moura@hotmail.com 
análises de PCR. Além disso, os resultados do histopatológico e ELISA sugerem que os animais-contato não tiveram tempo suficiente para demonstrar lesões ou resposta imune.

Palavras-chave: avaliação, avicultura, desenvolvimento, micoplasmas, vacina

\section{INTRODUCTION}

Mycoplasma gallisepticum causes severe economic losses to the poultry industry. Considering that eradication through elimination of positive flocks is expensive, available vaccines do not protect against infection, and the disease is difficult to effectively treat, new alternatives are needed to control the disease.

Mycoplasma synoviae (MS) and Mycoplasma gallisepticum (MG) are avian pathogens that can both cause respiratory infections. In addition, MG infection can lead to egg production losses and MS causes articular infections (Yoder, 1991). Mycoplasmas have oval, filamentous or flask shapes, and several pathogenic species display a prominent polar tip organelle or bleb structure that mediates attachment to the host target cells. This tip structure is hemispherical, around $800 \times 1250 \mathrm{~A}$ in circumferences and composed of surface-exposed proteins, called adhesins or cytadhesions proteins. These adhesins promote the attachment of mycoplasma allowing the colonization of epithelial cell surfaces (Dybvig and Voelker, 1996; Razin et al., 1998). The percentage of proteins in Mycoplasma membranes is much higher than other prokaryotes. These proteins are considered to be the most dominant antigens and are responsible for antigenic variation (Razin et al., 1998).

A 583 base pair portion of a MG cytadhesin gene was identified using degenerate primers designed from highly conserved sequences found in the human mycoplasmas $M$. pneumoniae and $M$. genitalium. Southern hybridization showed that the gene was not present in other avian $(M$. synoviae, $M$. meleagridis, $M$. iowae, $M$. gallinarum) and human mycoplasmas ( $M$. pneumoniae, $M$. genitalium). Thus, it shows potential for use as a diagnostic probe for MG (Dohms et al., 1993). Later, this 583-bp portion of the MG cytadhesin gene was used to probe a M. gallisepticum genomic library constructed with LambdaGEM-11. An eight Kb, Sac I fragment, was purified from the clone and used to construct a plasmid pMG25. Within pMG25 two open reading frames (ORFs) have been identified (Keeler et al., 1996).

Analysis of a 3,750 bp region of pMG25 showed a 3,666 bp ORF named mgc1 (Keeler et al., 1996). An oligonucleotide primer was designed from the mgc1 gene sequence and by Northern analysis it proved to hybridize to a specific MG RNA. This RNA codes for a 1,112 amino acid protein of $121 \mathrm{kDa}$. Comparison of the sequence for mgc1 that encodes for M. pneumoniae P1 and M. genitalium MgPA, revealed $37.4 \%$ and $42.3 \%$ homology, respectively, at the nucleotide level and $28.7 \%$ and $26.3 \%$ respectively, at the amino acid level (Keeler et al., 1996).

This experiment was performed to verify the use of MGC1 and MGC2 proteins as possible candidates for a vaccine against $\mathrm{MG}$ able to produce high antibody levels and to prevent MG infection by air sac inoculation or through horizontal transmission.

\section{MATERIAL AND METHODS}

A portion of the mgcl gene (390-bp HincII fragment) was cloned into pGex $3 \mathrm{X}$ (an expression plasmid), creating a pGex-in. The pGex-in expresses a $37 \mathrm{kDa}$ fusion protein (26$\mathrm{kDa}$ GST protein and 11-kDa MG-MGC1 protein). This fusion protein was electrophoresed on a SDS-10\% polyacrylamide gel. The gel portion corresponding to the predicted migration position of the fusion protein was homogenized with Freund's complete adjuvant and used to immunize rabbits. Three doses were administrated in rabbits by the subcutaneous and intramuscular routes. Rabbit serum was used to identify the mgcl protein in Western blot analysis. This technique identified a larger $(150 \mathrm{kDa})$ protein.

Another plasmid was used to construct a MGC1 fusion protein. The $\mathrm{mgcl}$ region corresponding to nucleotides 2425 through 2958 (amino acids 809 through 986) were cloned into the pQE30 vector (Qiagen Inc., Santa Clarita, CA) and expressed in E.coli cells SG13009[pRep4]. This produces a portion of the MGC1 protein fused to 
six histidines. This $6 x$ His tagged fusion protein was purified using a Nickel-NTA resin (Qiagen Inc., Santa Clarita, CA). In this purification system the His tag binds to nickel. The predicted molecular weight of the clone MGC1 protein fragment is about $22.5 \mathrm{kDa}$.

A second putative cytadhesion gene was identified in a $1.3 \mathrm{~kb}$ region of Pmg25, upstream of $\mathrm{mgc} 1$. This gene, $\mathrm{mgc} 2$, has an open reading frame of 912 nucleotides. The MGC2 protein contains 304 amino acids, and has a mass of $32.7 \mathrm{kDa}$. The sequence coding for MGC2 was found to be $40.9 \%$ identical to the sequence coding for cytadhesion P30 in M. pneumoniae. The predicted molecular weight of MGC2 and fusion protein is around $63 \mathrm{kDa}$. MGC2 proved to be located at the tip organelle in MG through immunogold labeling and its anti-serum is able to prevent attachment of MG to chicken embryo fibroblasts (CEF) cells (Hnatow et al., 1998).

E. coli recombinant $\mathrm{MGC} 1$ and $\mathrm{MGC} 2$ from $70^{\circ} \mathrm{C}$ stocks were grown in $600 \mathrm{~mL}$ of sterile LB (10g tryptone; $1 \mathrm{~g} \mathrm{NaCl} ; 5 \mathrm{~g}$ Yeast extract; $\mathrm{pH}$ 7.4) with ampicillin $(100 \mu \mathrm{g} / \mathrm{mL})$ and kanamycin $(25 \mu \mathrm{g} / \mathrm{mL})$ grown at $37^{\circ} \mathrm{C}$ overnight with vigorous shaking. When the optical density (at $600 \mathrm{~nm}$ ) was between 0.7-0.9 wavelengths, a control pre induction sample was collected and $1 \mathrm{M}$ of Isopropyl- $\beta$-D-Thiogalactopyranoside (IPTG) was added to the remaining culture. Two hours following IPTG addition, a second sample of the culture was collected. To check for IPTG induction of MG proteins pre and post IPTG samples were electrophoresed overnight at $200 \mathrm{~m}$ $\mathrm{V}$ on two SDS polyacrylamide mini-gel (15\% for MGC1 and $12 \%$ for MGC2) with a $5 \%$ SDS stacking gel. To verify correct protein size, markers were also added to the gels (Bio-Rad Kaleidoscope Prestained Standards, Hercules, CA). Gels were stained with Coomassie brilliant blue and distained.

After two hours of induction, cells were harvested by centrifugation at $10 \mathrm{~K}$ for $15 \mathrm{~min}$, at $4^{\circ} \mathrm{C}$. The pellet was re-suspended in $25 \%$ sucrose. Two hundred microliters of Tris- $\mathrm{HCl}$ (50mM, pH 8) were added for each $10 \mathrm{~mL}$ of the original LB culture and the suspension was frozen at $-20^{\circ} \mathrm{C}$ for $15 \mathrm{~min}$.

The frozen suspension was thawed and $200 \mu \mathrm{L}$ of lysozyme $(10 \mathrm{mg} / \mathrm{mL})$ in Tris- $\mathrm{HCl}(0.25 \mathrm{M}$; $\mathrm{pH} 8)$ were added. Samples were incubated for $20 \mathrm{~min}$ in ice. A $1.4 \mathrm{~mL}$ volume of TET buffer $(100 \mathrm{mM}$ Tris- $\mathrm{HCl} \mathrm{pH} 8.0 ; 50 \mathrm{mM}$ EDTA; 2\% Triton X100) was added and gently mixed. This was followed by incubation in ice for $5 \mathrm{~min}$. Next, $1.75 \mathrm{~mL} 2 \mathrm{X}$ RIPA buffer (20mM Tris- $\mathrm{HCl} \mathrm{pH}$ 7.4; 300mM NaCl; 2\% Sodium deoxycholate; $2 \%$ NP-40; $0.2 \%$ SDS) was added and gently mixed. Samples were incubated in ice for $5 \mathrm{~min}$. Then, samples were sonicated in ice for 10 seconds at setting \#2 on the sonicator Vibra Cell (Sonics and Materials Inc., Danbury, CT). Samples were centrifuged in Sorvall-AH629 rotor (Du Pont Company; Wilmington, DE) for $10 \mathrm{~min}$ at $15 \mathrm{~K}$ at $4^{\circ} \mathrm{C}$. The pellet was resuspended in $300 \mu \mathrm{L}$ of water. Each sample $(5 \mathrm{~mL})$ was added to the appropriate amount of loading buffer (50mM Tris-HCl, $\mathrm{pH} 6.8 ; 100 \mathrm{mM}$ dithiothreitol; $2 \%$ SDS; $0.1 \%$ of bromophenol blue; $10 \%$ glycerol) and boiled at $95-100^{\circ} \mathrm{C}$ for 5 min to dissolve the pellet. Samples were loaded onto SDS-polycrylamide gel (12\% for MGC1 and $10 \%$ for MGC2) with a $3 \%$ stacking gel and eletrophoresed overnight at $75 \mathrm{mV}$. BenchMar prestained protein ladder markers $(10$ to $200 \mathrm{KDa}$ ) were used in each gel to aid the identification of the correct band size $(22.5 \mathrm{kDa}$ for $\mathrm{MGC1}$ and $63 \mathrm{kDa}$ for $\mathrm{MGC} 2$ ). Electrophoresis was conducted until all the bromophenol blue dye reached the bottom of the gel. The correctly sized bands were cut from the gel and frozen at $-20^{\circ} \mathrm{C}$.

Frozen gels were electroeluted and the final desired protein concentration for each oil emulsion vaccine batch was determined using a colorimetric assay similar to the Lowry Assay (Bio-Rad DC Protein Assay protein; Bio-Rad Laboratories, Hercules, CA). After the determination of protein concentration, protein samples were streaked in blood agar and incubated at $37^{\circ} \mathrm{C}$ for 24 to 72 hours to check for possible bacterial contamination. No growth was observed in any blood agar plate demonstrating that all $E$. coli cells had been lysed and that no other bacterial contamination was present in the vaccine preparations.

The oil emulsion vaccine consisted of two phases: oil [7.2mL of Drakecol 6VR (Penreco Inc., Los Angeles, CA) and $0.8 \mathrm{~mL}$ of Arlacel 80 (Sigma Chemical Company, St. Louis, MO)] and an aqueous phase $(1.92 \mathrm{~mL}$ antigen and $80 \mu \mathrm{L}$ of Tween 80 ). The oil phase was incubated in an ice bath and the aqueous phase was slowly added 
drop wise and mixed over a two minute period. The suspension was then mixed at high speed for 30 seconds (Stone et al., 1978). Batches were prepared in an increasing order of protein concentration. The emulsifier was washed and rinsed with distilled water between different vaccine preparations. The 50, 100, 200, and $400 \mu \mathrm{g} / \mathrm{bird}$ solutions of protein were prepared such that each bird received $1 \mathrm{~mL}$ final volume. The $800 \mu \mathrm{g}$ preparation was diluted to $400 \mu \mathrm{g} / \mathrm{mL}$ and each bird received $2 \mathrm{~mL}$. The $1000 \mu \mathrm{g} / \mathrm{bird}$ group was diluted to $400 \mu \mathrm{g} / \mathrm{mL}$ and each bird received $1000 \mu \mathrm{g}$ in a total of $2.5 \mathrm{~mL}$. The membrane control was prepared similarly to the $1000 \mu \mathrm{g} / \mathrm{bird}$ group. The oil emulsion group contained only oil phase and PBS as aqueous phase and each bird received $1 \mathrm{~mL}$.
This work was performed under the approval from the University of Delaware Institutional Animal Care and Use Committee (IACUC). One hundred and forty six, SPF, mixed sex, one week-old, SCWL chickens were vaccinated against Marek's disease and IBDV (variant strain), and placed in colony houses in the University of Delaware Agriculture Experimental Station. Birds had free Access to food and water. They were divided into seventeen groups (Table 1).

At four weeks of age, birds were wing banded, bled and received the first vaccine dose, which were administrated subcutaneously in the upper region of the neck. Three weeks later, chickens were bled and a second identical dose was administered.

Table 1. M. gallisepticum subunit oil emulsion vaccine treatments using two subcutaneous inoculations at three week intervals into three week-old specific-pathogen-free chickens

\begin{tabular}{l|l|l|l|l|l}
$\mathrm{MGC}^{\mathrm{a}}(\mu \mathrm{g} / \mathrm{bird})$ & $\mathrm{n}$ & $\mathrm{MGC}^{\mathrm{a}}(\mu \mathrm{g} / \mathrm{bird})$ & $\mathrm{N}$ & Controls & $\mathrm{n}$ \\
\hline
\end{tabular}

\begin{tabular}{|c|c|c|c|c|c|}
\hline 50 & 09 & - & - & - & - \\
\hline 100 & 09 & - & - & - & - \\
\hline 200 & 09 & - & - & - & - \\
\hline 400 & 10 & - & - & - & - \\
\hline 800 & 10 & - & - & - & - \\
\hline 1000 & 10 & - & - & - & - \\
\hline- & - & 50 & 09 & - & - \\
\hline - & - & 100 & 10 & - & - \\
\hline- & - & 200 & 09 & - & - \\
\hline- & - & 400 & 10 & - & - \\
\hline- & - & 800 & 10 & - & - \\
\hline- & - & 1000 & 10 & - & - \\
\hline- & - & - & - & Bacterin $^{\mathrm{b}}$ & 09 \\
\hline- & - & - & - & Membrane ${ }^{c}$ & 04 \\
\hline- & - & - & - & No vaccine & 04 \\
\hline & & & & Challenge $^{\mathrm{d}}$ & \\
\hline - & - & - & - & Oil emulsion ${ }^{\mathrm{e}}$ & 04 \\
\hline- & - & - & - & No vaccine, Challenge $\mathrm{f}^{\mathrm{f}}$ & 10 \\
\hline
\end{tabular}

${ }^{\mathrm{a}} \mathrm{MGC} 1$ and MGC2 MG cytadhesion proteins were used as an experimental vaccine given subcutaneously in the upper neck on different concentrations.

${ }^{\mathrm{b}}$ Commercial MG oil emulsion bacterin was donated by Vineland Laboratories Inc., Vineland, NJ.

${ }^{c} \mathrm{MG}$ membrane preparation contained $400 \mu \mathrm{g} / \mathrm{mL}$ antigen.

${ }^{\mathrm{d}}$ Negative controls were injected with $0.2 \mathrm{~mL}$ Frey Broth.

${ }^{\mathrm{e}}$ Oil-emulsion control contained only oil phase and PBS.

${ }^{\mathrm{f}}$ Challenged with $0.2 \mathrm{~mL}$ of Frey Broth containing MG at $10^{6} \mathrm{CFU} / \mathrm{mL}$.

There were five treatment control groups. The bacterin control group received two doses of $1 \mathrm{~mL}$ of the commercial inactivated vaccine (Vineland Laboratories Inc., Vineland, NJ). Membrane and oil emulsion groups were inoculated as described previously. One group, called no vaccine but challenged, did not receive any vaccine preparation and was challenged at ten weeks of age. The negative control group (no vaccine or challenge) was injected into the right thoracic air sac with $0.2 \mathrm{~mL}$ of only Frey Broth.

Three weeks after the last vaccination, $50 \%$ of all birds in each group (with the exception of the oil 
emulsion and no vaccine or challenge control groups), were challenged with $0.2 \mathrm{~mL}$ of Frey Broth containing $\mathrm{MG}$ S6 at $10^{6} \mathrm{CFU} / \mathrm{mL}$ ( $\left.2 \times 10^{5} \mathrm{CFU} / \mathrm{bird}\right)$, in the right caudal thoracic air sac. The remaining birds were not challenged but left as contacts to determine horizontal transmission. Chickens were killed using carbon dioxide and necropsy was performed ten days after the challenge. Contact birds stayed in the colony house for an additional 4 days and then necropsied. Air sac lesions were scored from zero to four, according to the severity of their lesions.

Lower bursal/body weight ratio is related to immunosuppression by infectious bursal disease virus (IBDV) (Pope, 1991). The immunosuppression (IS) caused by IBDV could interfere in this vaccine Trial. Thus, bursas of Fabricius were collected and the lowest bursal/body weight ratio was 3.64 , indicating that IBDV infection did not occur.

Samples from all birds were tested for antibodies to $\mathrm{MG}$ by a rapid serum plate agglutination test with commercial antigen (Intervet Inc., Millsboro, DE) by mixing similar amounts $(50 \mu \mathrm{L})$ of serum sample to be tested and stained MG cell on a glass plate. The plate should be rotated for $2 \mathrm{~min}$ and a clump formation will indicate a positive reaction.

Swabs were obtained from the mucosae of the upper part of the trachea, in a region not collected for histopathology. Each swab was inoculated into Frey Broth and incubated at $37^{\circ} \mathrm{C}$ for 24 hours. After this time, all swabs were removed and only the Frey Broth was left at $37^{\circ} \mathrm{C}$ until the phenol red indicator in the medium had changed to yellow. All tubes that had turned yellow were frozen at $-20^{\circ} \mathrm{C}$ for $\mathrm{MG}$ confirmation by MG specific PCR assay.

A $100 \mu \mathrm{L}$ aliquot of thawed samples was pooled by treatment group. Samples were centrifuged at $14.000 \mathrm{rpm}$ for two min. The cell pellet was resuspended in sterile distilled water, brought to $100^{\circ} \mathrm{C}$ for $5 \mathrm{~min}$., cooled for at least $5 \mathrm{~min}$., and then re-centrifuged for $5 \mathrm{~min}$. A $20 \mu \mathrm{L}$ aliquot of the supernatant was combined with $30 \mu \mathrm{L}$ of a master mix $(377 \mu \mathrm{L}$ of sterile distilled water; $5 \mu \mathrm{L}$ of 10X magnesium-free termophilic buffer; $5 \mu \mathrm{L}$ of $25 \mathrm{mM} \mathrm{MgCl} 2 ; 50 \mathrm{pmol}$ of primers C2-5L 5' and 50 pmol of primer PR 24L 3' [Ranson Hill
Bioscience, In., Ramona, CA]; $0.5 \mu \mathrm{L}$ of Taq DNA Polymerase (5units/ $\mu \mathrm{L}) ; 1 \mu \mathrm{L}$ of dNTPs containing $10 \mathrm{mM}$ of each of the dinucleotides (dATP, dCTP, dGTP, dTTP). All reagents were obtained from Promega Corp., Madison, WI. The primers used flank a $250 \mathrm{bp}$ fragment of the putative mgc2-MG S6 cytadhesin gene and are composed of the following sequence:

\section{C2-5L 5' TGGTGTTCTTCACGTTCTTGGATC 3'} PR24L 5' GGTGCTATTGCGCTTGGAACTGG 3'

The PCR reaction was conducted using Thermocycler (Hybaid Thermal Cycler, Ashford, Middlesex, UK). DNA was denatured at $95^{\circ} \mathrm{C}$ for $3.5 \mathrm{~min}$. Primers were allowed to anneal at various temperatures and extension occurred during one minute at $72^{\circ} \mathrm{C}$. For the first 5 cycles, annealing occurred at $65^{\circ} \mathrm{C}$, for the next 10 cycles, the annealing temperature was reduced to $60^{\circ} \mathrm{C}$, and for the last 30 cycles annealing occurred at $53^{\circ} \mathrm{C}$. The amplified PCR products were run on a $1.2 \%$ agarose gel, stained with ethidium bromide and visualized on an UV illuminator and photographed. The size of PCR products was determined using $1 \mathrm{~kb}$ DNA marker (Gibco BRL, Gaithersburg, MD).

Trachea, syrinx, lungs and air sacs of all birds used in this trial were fixed in $10 \%$ buffered formalin solution. The right caudal thoracic air sac was the inoculation site for the challenge and was collected for histopathology. The trachea, syrinx and lungs were collected together as one unit. All samples were embedded in paraffin, sectioned $(5 \mu \mathrm{m})$, and stained with hematoxylin and eosin. Lesions were scored as follows: $0=$ not significant; $1=$ minimal change; $2=$ moderate change; $3=$ severe change. The lesion scores in challenged and contact birds were averaged.

\section{RESULTS AND DISCUSSION}

The serum plate agglutination test (SPA) was performed on samples from all bleeding time points. The pre-inoculation serum samples tested were negative as expected. Three weeks after the first vaccine dose approximately $50 \%$ of the birds were SPA tested (bleed 1). Weak positive reactions were obtained in MGC1 - 50 (1/6), 100 (2/7), 200 (4/6), 400 (2/5), 800 (2/2), and $1000 \mu \mathrm{g} / \mathrm{bird}$ dose groups (1/6). For MGC2 groups the results were: 50 (1/6), $100(4 / 6), 200$

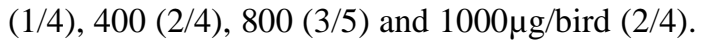


All birds from the bacterin group were SPA positive (6/6) with strong agglutination reactions. In the MG-membrane group, $50 \%$ of the birds tested were (2/4) positive and their reactions were intermediate between those obtained in the treatment groups and bacterin controls. Three weeks after the second vaccine dose, $100 \%$ of the birds were SPA tested (bleed 2). Positive reactions were observed in groups MGC1 - 50 (4/9), 100 (5/9), 200 (5/9), 400 (3/10), 800 $(4 / 10)$, and $1000 \mu \mathrm{g} / \mathrm{bird}(5 / 10)$ and MGC2 - 50 (3/9), 100 (4/10), 200 (4/9), 400 (6/10), 800 $(5 / 10)$ and $1000 \mu \mathrm{g} /$ bird (4/10). Strong positive reactions were observed in $100 \%$ of the bacterin (9/9) and MG-membrane (4/4) control groups. At the last bleed, after the challenge, all birds were positive in the SPA test.

All birds showed very low optical density (OD) reading at the ELISA test pre-inoculation sampling, confirming the SPA results. Differences obtained between treatment groups were not significant $(p=0.1044)$. At the first bleed, three weeks after the first vaccine dose, all birds showed an immune response with higher O.D. than pre-vaccination samples ranging between 0.31-0.57 for MGC1 and 0.27-0.54 for MGC2 However, surprisingly, MGC1$800 \mu \mathrm{g} / \mathrm{bird}$ and MGC1-1000 $\mu \mathrm{g} / \mathrm{bird}$ were lower than any other doses. Three weeks after second vaccine dose, all treatments had a higher O.D. reading than at first bleed, except $\mathrm{MGC1}$ $100 \mu \mathrm{g} / \mathrm{bird}$ with a slightly lower reading (0.560.57). Significant differences were found between treatment groups (MGC2 50, 100 and $1000 \mu \mathrm{g} / \mathrm{bird}$ ). At the first necropsy (third bleed) performed ten days after the challenge, birds in all treatment groups showed a higher antibody. In the membrane control group, antibody levels remained the same as after the challenge. The Bacterin control group showed the highest titer during the entire experiment, decreasing only after the challenge was performed. The unvaccinated and unchallenged control group had low O.D. through the entire experiment.

Incidence, mean and standard error for air sac lesions are presented on Table 2. A significant difference $(p<0.05)$ was observed in the treatment group MGC2-50 $\mu \mathrm{g} / \mathrm{bird}(1.80 \pm 0.22)$ when compared to the unvaccinated and unchallenged control group.

Table 2. Summary of the airsacculitis lesion incidence and severity at the necropsy of specific-pathogenfree chickens vaccinated with two subcutaneous doses of either MGC1 or MGC2 oil emulsion vaccine and challenged with $2 \times 10^{5} \mathrm{CFU}$ of $M$. gallisepticum $\mathrm{S} 6$ three weeks after last vaccination

\begin{tabular}{|c|c|c|c|}
\hline \multirow[t]{2}{*}{ Vaccine } & \multirow{2}{*}{$\begin{array}{l}\text { Treatments } \\
(\mu \mathrm{g} / \mathrm{bird})\end{array}$} & \multicolumn{2}{|c|}{ Airsacculitis $^{\mathrm{a}}$} \\
\hline & & Incidence $^{\mathrm{b}}$ & Mean Score \\
\hline \multirow[t]{6}{*}{ MGC1 } & 50 & $5 / 5$ & $0.60 \pm 0.22$ \\
\hline & 100 & $5 / 5$ & $1.05 \pm 0.22$ \\
\hline & 200 & $5 / 5$ & $1.15 \pm 0.22$ \\
\hline & 400 & $4 / 5$ & $0.60 \pm 0.22$ \\
\hline & 800 & $4 / 5$ & $0.90 \pm 0.22$ \\
\hline & 1000 & $5 / 5$ & $1.00 \pm 0.22$ \\
\hline \multirow[t]{6}{*}{ MGC2 } & 50 & $5 / 5$ & $1.80 \pm 0.22 *$ \\
\hline & 100 & $2 / 5$ & $0.40 \pm 0.22$ \\
\hline & 200 & $3 / 5$ & $0.45 \pm 0.22$ \\
\hline & 400 & $4 / 5$ & $0.40 \pm 0.22$ \\
\hline & 800 & $3 / 5$ & $0.65 \pm 0.22$ \\
\hline & 1000 & $2 / 5$ & $0.30 \pm 0.22$ \\
\hline \multirow[t]{5}{*}{ Controls } & Bacterin & $3 / 5$ & $0.45 \pm 0.22$ \\
\hline & Membrane & $1 / 2$ & $0.25 \pm 0.35$ \\
\hline & No vaccine or challenge & $0 / 4$ & ND \\
\hline & Oil emulsion & $1 / 3$ & $0.19 \pm 0.25$ \\
\hline & No vaccine, challenge & $3 / 5$ & $0.55 \pm 0.22$ \\
\hline
\end{tabular}

\footnotetext{
${ }^{\mathrm{a}}$ Air sac lesions scores 14 days after challenge were all zero.

${ }^{\mathrm{b}}$ Number of birds with lesions/number of birds examined.

*Significantly different $(\mathrm{P}<0.05)$ by Tukey-Kramer adjustment for multiple comparisons.
} 
Not surprisingly, since all birds were challenged, all samples had a PCR product amplified of $250 \mathrm{bp}$, except the unvaccinated and unchallenged group. A sample from MG S6 strain served as positive control and Frey Broth as negative control.

Microscopic lesions were detected in the respiratory tract in this experiment. Those lesions were more marked in challenged birds and very mild or inexistent in those contact challenged. The site of MG air sac inoculation caused a severe inflammatory response as demonstrated by lymphocytic infiltration and germinal center formation. Pleura were not one of the main tissues to be collected. However, in some lung samples, pleura were examined. Severe serositis was characterized by edema, diffuse lymphocytic heterophilic infiltration, and numerous germinal centers. Pneumonia was diagnosed when an abnormal heterophilic response was observed. In most cases there was an intense infiltration by macrophages, heterophils and lymphocytes in the trachea, syrinx, primary bronchi, air sacs, pleura and lungs. These findings suggest an ascendant migration of the inflammatory response from inoculation site to pleura and lungs.

Horizontal transmission was verified by reisolations, PCR, air sac lesions, antibody response by indirect ELISA and SPA. Reisolations are shown on Table 3. Only three samples in Frey Broth turned from color red to yellow (MGC1 - 100, 800, and 1000). Only a few samples from contact birds (MGC1 - 100, 800 , and $1000 \mu \mathrm{g} /$ bird treatment groups) gave positive results in PCR (data not shown). Antibody response shows a slight decrease in O.D. readings comparing those observed before birds were put in contact with challenged birds. In contrast, bacterin and membrane groups had an increased response, suggesting that the commercial and membrane vaccine inoculation did not demonstrate full potential at three weeks. The same contact birds that showed positive results in SPA before the challenge, also showed positive results after contact. Bacterin and membrane controls had all positive samples (4/4 and $2 / 2$, respectively). The non-vaccinated, unchallenged birds were all SPA negative (0/5).

Table 3. Summary of the M. gallisepticum reisolation rate following two subcutaneous doses of either MGC1 or MGC2 oil emulsion vaccine and challenge with $2 \times 10^{5} \mathrm{CFU}$ of $M$. gallisepticum S6 three weeks after last vaccination

\begin{tabular}{ll|cc}
\hline Vaccine & \multicolumn{1}{c}{$\begin{array}{c}\text { Treatments } \\
(\mu \mathrm{g} / \mathrm{bird})\end{array}$} & \multicolumn{2}{c}{ Reisolation $^{\mathrm{a}}$} \\
\cline { 3 - 4 } MGC1 & 50 & $3 / 5$ & Challenged $^{\text {Contacts }^{\mathrm{b}}}$ \\
& 100 & $4 / 5$ & $0 / 4$ \\
& 200 & $5 / 5$ & $0 / 4$ \\
& 400 & $5 / 5$ & $0 / 5$ \\
& 800 & $5 / 5$ & $1 / 5$ \\
MGC2 & 1000 & $4 / 5$ & $1 / 5$ \\
& 50 & $4 / 5$ & $0 / 4$ \\
& 100 & $5 / 5$ & $0 / 5$ \\
& 200 & $4 / 5$ & $0 / 4$ \\
& 400 & $4 / 5$ & $0 / 5$ \\
& 800 & $5 / 5$ & $0 / 4$ \\
Controls & 1000 & $4 / 5$ & $0 / 5$ \\
& Bacterin & $3 / 5$ & $0 / 4$ \\
& Membrane & $3 / 4$ & $0 / 2$ \\
& No vaccine or challenge & $0 / 4$ & $\mathrm{ND}$ \\
& Oil emulsion & $2 / 4$ & $\mathrm{ND}$ \\
& No vaccine, challenged & $5 / 5$ & $0 / 5$ \\
\hline
\end{tabular}

${ }^{a}$ Tracheal swabs from individual chickens were inoculated into Frey Broth and incubated at $37^{\circ} \mathrm{C}$. Reisolations were confirmed using MG-specific PCR.

${ }^{\mathrm{b}}$ Samples from birds challenged by contact.

${ }^{\mathrm{c}} \mathrm{ND}=$ not determined. All birds from no vaccine or challenge and oil emulsion groups received MG S6 challenged into de caudal thoracic air sac.

*Significant different $(\mathrm{P}<0.05)$ by Tukey-Kramer adjustment for multiple comparisons. 


\section{CONCLUSIONS}

A novel approach to vaccinate chickens against mycoplasmosis was attempted in this study. Even though it was possible to show humoral immunity for both MG cytadhesion proteins tested into an oil emulsion vaccine, protection against infection and disease was not observed after two doses tested with six different concentrations, indicating that Mycoplasmas may have ways to overcome humoral immunity.

\section{ACKNOWLEDGEMENTS}

We thank the University of Delaware for providing funds for this research and Ms. Linda Hnatow for her technical assistance.

\section{REFERENCES}

DYBVIG, K.; VOELKER, L.L. Molecular biology of mycoplasmas. Ann. Rev. Microbial, v.50, p.25-27, 1996.

DOHMS, J.E.; HNATOW, L.L.; WHETZEL, P. et al. Identification of the putative cytadhesion gene of Mycoplasma gallisepticum and its use as a DNA probe. Avian Dis., v.37, p.380-388, 1993.

HNATOW, L.L.; KEELER, C.L.; TESSMER Jr., L.L. et al. Characterization of $\mathrm{MGC} 2$, a Mycoplasma gallisepticum cytadhesin with homology to the Mycoplasma pneumoniae 30kilodalton protein P30 and Mycoplasma genitalium P32. Infect. Immun., v.66, p.34363442, 1998.
KEELER Jr, C.L.; HNATOW, L.L.; WHETZEL, P.L.; DOHMS, J.E. Cloning and characterization of a putative cytadhesin gene ( $m g c l)$ from Mycoplasma gallisepticum. Infect. Immun., v.64, p.1541-1547, 1996.

POPE, C. Pathology of lymphoid organs with emphasis on immunosuppression. Vet. Immunol. Immunopath., v.30, p.31-44, 1991.

RAZIN, S.; YOGEV, D.; NAOT, Y. Molecular biology and pathogenicity of mycoplasmas. Microbiol. Mol. Bio. Rev., v.62, p.1094-1156, 1998.

STONE, H.D.; BRUGH, M.; HOPKINS, S.R. et al. Preparation of inactivated oil-emulsion vaccines with avian viral or mycoplasma antigens. Avian Dis., v.22, p.666-674, 1978.

YODER, H.W. Mycoplasma gallisepticum infection. In: CALNEK, B.W.; BEARD, C.W.; BARNES, H.J. et al. Diseases of Poultry. 9nd ed. Ames/Iowa: Iowa State University Press, 1991. p.198-212. 